\title{
Factors Influencing Tribal Farming: Case of Attappadi Tribes in Kerala
}

\author{
P. C. Sachana* and Binoo P. Bonny \\ Department of Agricultural Extension, College of Horticulture, Kerala Agricultural \\ University, Thrissur-686656, India \\ *Corresponding author
}

\section{A B S T R A C T}

Keywords

Agriculture,

Climate change,

Animal menace, Policy

\section{Article Info}

Accepted:

26 May 2020

Available Online:

10 June 2020
Majority of the tribes in Kerala continue to depend on agriculture and are struggling to compete with the current situational threats like climate change and wild animal menace. Traditionally tribal communities in Attappadi depended on agriculture based on indigenous knowledge gained through oral tradition and practice over generations for their livelihood. Delineation of the factors influencing the selection of farming techniques and strategies among tribal farmers needed to be addressed by the scientists and the policymakers for the implementation of developmental projects in the Attappadi area. It was done based on a set of statements selected through literature review and expert rating. Data collected was analysed using factor analysis to delineate the factors. Agricultural technology and input services, policy, knowledge and information support, infrastructure, weather \& technological constraints, farm management and market orientation and access to extension services were found to be the factors determining for the selection of farming strategy and agricultural technologies.

\section{Introduction}

Kerala has achieved remarkable improvement in the social sector, celebrated as 'Kerala Model of Development'. But it is observed that the development process fell short to encompass tribal communities in the course. Majority of the tribes in Kerala continue to depend on agriculture and are struggling to compete with the current situational threats like climate change and wild animal menace. Moreover, the commercial exploitation of forest resources has resulted in extensive soil erosion and loss of soil fertility. Therefore sustaining crop production and productivity without damaging the resources and environment are posing big challenge to the tribal farming.

This threatened the livelihood of the tribal community which depended on agriculture and forest, forcing them to be bonded and migrant labour (Patidar et al., 2018). In this context the tribal strategies to cultivate different crops in predetermined areas and sustainable farming techniques which 
enhance the capacity of land to rejuvenate natural vegetation and water resources assume great significance. The paper discusses the results of the study that attempted to delineate the factors influencing the selection of farming techniques and strategy among tribal farmers

\section{Materials and Methods}

\section{Study area}

Palakkad known as the granary of Kerala formed the study area. It is the largest district and is bordered on north by Malappuram district, on the south by Thrissur district, on the west by Thrissur and Malappuram districts and east by Coimbatore district of Tamil Nadu. Attappadi, one of the prominent forest regions of Kerala is situated in the north eastern part of Palakkad and was selected as the study area (Fig. 1).

Attappadi block formed one of the 43 tribal development blocks in India having predominant tribal population. The tribal people of Attappadi reside in small nuclear villages called Ooru. Each Ooru contains, on an average, 50 houses constructed in rows, close to one another. The Irulas form the majority among the tribes and live in 144 hamlets

\section{Study sample}

The study was conducted in three purposively selected panchayats of the Attappadi tribal developmental block namely Attappadi I (Agali panchayat), Attappadi II (Pudur panchayat) and Attappadi III (Sholayur panchayat).

One hundred tribal families were randomly selected from each panchayath. Thus a total of 300 randomly selected tribal families formed the study sample.
Measurement of factors influencing the selection of farming techniques and strategies

Delineation of the factors influencing the selection of farming techniques and strategies among tribal farmers were made based on a set of statements selected through literature review and expert rating. Pretesting of selected statements were done in a nonsampling area among 30 randomly selected respondents. In order to determine the relative position of the farmer's scores, the response to each statement in the module was coded either in affirmative or negative (1 or 0) and the total was computed. Selected statements were given for judges rating and 23 statements with more than fifty per cent score were selected for the measurement tool. The set of questions included in the core survey module was combined into a single overall measurement scale so as to have a continuous, linear scale which is measured in a single numerical value ranging from 0 to 23 .

The content validity method through judges rating was used to determine the questionnaire validity. The reliability of the instrument was measured using Cronbach's Alpha statistics and was found to be 0.923 which showed high reliability acceptable enough to be used in data collection.

\section{Analysis of data}

Data collected was analysed using factor analysis to delineate the factors that influenced the tribal farmers in their use of farming and adaptation strategies. Analyses were conducted using SPSS software for Windows version 9.2. It helped to reduce the dimensionality of the dataset down to fewer unobserved variables. Descriptive Statistics that were used in this work was the frequency and percentages in evaluating profiles of respondents. 


\section{Results and Discussion}

\section{Socio-economic profile of Attappadi tribes}

The distribution of tribal people, with respect to various profile characteristics (Table 1) and the discussions relevant to those characteristics are presented. The variables studied under profile characteristics were educational status, social participation, contact with extension agency, leadership quality, media exposure, innovativeness, monthly expenditure, monthly income, concern towards weaker section, availability of electric power, sanitation facility, type of house, distance to drinking water and land owned.

\section{Major occupations of Attappadi tribes}

Traditionally tribal communities in Attappadi depended on agriculture based on indigenous knowledge gained through oral tradition and practice over generations for their livelihood. The prevalence of community ownership of land among them had the advantage of providing access to required land for cultivation.

This enabled them to grow their traditional crops in sufficient quantities that ensured their food and nutritional security. Major traditional crops cultivated included millets, pulses and oilseeds such as makkacholam or maize (Zea mays), ragi or french millet (Eleusine coracana), chama or little millet (Panicum miliaceum), thuvara or red gram (Cajanus cajan), groundnut (Arachis hypogeae) and castor (Ricinus communis).

However, the introduction of the government policy of granting individual ownership of land under the Government Land Assignment Acts caused land alienation in tribal areas (Sachana, 2015).
Lack of awareness and adeptness in handling individual property among tribal people was exploited by outsiders leading to their loss of rights on land. According to Sankar and Muraleedharan (1990) farming in Attappadi area in recent years have transformed into a mix of traditional practices like shifting cultivation and modern day methods like protected cultivation.

This lead to deforestation and unsustainable agricultural practices which had its dent in the tribal agro-ecosystem causing unpredictable rains, dried rivers and degraded soils. This endangered agriculture as the mainstay of the majority of the tribal population forcing them to abandon the cultivation of traditional food crops. This had significant impact on nutritional security and health in the region resulting in wide spread anemia and other diseases.

Majority who left agriculture turned out to be migrant laborers in plantations and construction sites in Karnataka due to limited job opportunities in the area. Some depended on the collection and sale of non-timber forest products (NTFP) such as lac, honey, medicinal plants etc.

Those few who continued in agriculture shifted to new crops due to falling yields, recurring pest and diseases and inefficient practices. Premakumar et al., (2015) reported a transition in cropping pattern in the region from a three crop combination of fruits, spices and tuber to four crop combinations of fruits, spices, vegetables and tuber during the period 2001-2011. Presently a minor group has even integrated some of the modern techniques of agriculture like micro irrigation, mulching etc. with the assistance of the Department of Agriculture. Details of crops grown along with the season of cultivation collected in field survey of the study area are presented as Table 2 . 


\section{Farming practices of tribal farmers}

Majority of tribal farms still depend on traditional indigenous practices such as the use of traditional seeds, hand weeding, intercultural operations using traditional tools etc. The traditionally conserved seeds are shared by farmers within the community. Conventionally seeds like cowpea are coated with clay and are conserved in air tight wooden as well as clay bottle like structures.

This practice is popular among the tribal communities as it conserves the seeds for one to two seasons. Traditional seeds of millets such as finger millet, pearl millet and sorghum grown by the tribes showed high climate resilience and were found ideal in environments prone to drought and extreme heat. Another significant finding was that majority of tribal farmers viewed agriculture not just as an economic activity but a process of co-existence with nature. Therefore, growing food without harming nature, the soil and the ecosystem guided their production practices rather than economics of yield and profit.

\section{Constraints and possibilities}

Though diverse agricultural information sources were prevalent in the region, farmers reported limitations with availability and access to reliable agricultural information. The available sources ranged from extension workers, community leaders, radio, television, film shows, documentaries, agricultural pamphlets, rural libraries, state and local government agencies in agriculture.

However, the use of formal libraries was limited as majority of tribal farmers were illiterate. Jalaja and Kala (2015) in their study on agricultural information needs of Attappadi tribal farmers found that majority of the farmers needed information related to the availability of seeds, crop production practices, and pest management. Geographical remoteness of the area ramified into exclusion from social agencies, educational institutions, business activities and information supply sources. The tribal communities lived in scattered and isolated areas that lacked infrastructural and social amenities (electricity, portable water, good roads, hospitals and schools). Moreover there was reported mismatch between available technologies and real-life needs especially in agriculture.

The available high-yielding cultivars did not suit their requirements, in terms of crop duration and grain quality needed for their food products. Climate vagaries in the form of irregular monsoon resulting in long dry spells and drought-like situations during early kharif (summer cropping) season and, untimely rain has become regular phenomenon. This has made the area conducive for the spread of many crop diseases and pests.

Another constraint reported was the damage caused to the agricultural self-reliance due to the spread of monoculture crops and plantations under development schemes implemented. These schemes failed to understand the value of diversity and conservation strategies followed in tribal farming and have caused serious harm to the tribal communities of the area.

\section{Factors influencing tribal farming}

Five factors were delineated using factor analysis that are independent of each other and are presented in Table 3. Each factor was derived from a weighted linear combination of agricultural variables that accounted for the largest total variation in the data. The factors extracted are given in the descending order of importance with respect to the proportion of the variance accounted by each factor. 
These five factors extracted together explained a total variance of 92.51 per cent which implied high significance of the selected variables. The results of the rotated factor matrix for the statements are presented in Table 4.

Though the general criterion of meaningful selection was factor loading score of 0.30 to 0.40 , the study used a factor loading score of $\geq 0.5$ to identify the most highly correlated variables in each factor as indicated by Tabachnick and Fidell (2001).

In addition, the eigenvalue for each factor extracted with values $>1$ which indicated that the factor explained more of the variance than could be accounted for by any one variable was selected. Thus number of factors in the model was determined based on the criteria that at least two variables with a loading score of $\geq 0.5$ in a factor; factors must have an eigenvalue $>1.0$; and each factor must account for at least $1 \%$ of the total variance.

Every variable in each factor had a factor loading score that represented the correlations between each of the variables included in each factor, similar to Pearson's correlation coefficients. The scree plot test which depicts the factors on the $\mathrm{x}$ axis and the corresponding eigenvalues on the $y$ axis was used to extract the five determining factors (Fig. 2). The test drops factors after the break of inflexion.

The results in Table 3 showed that the Factor 1 comprised of eight items with factor loadings ranging from 0.696 to 0.962 . Factor 2 comprised of six items with factor loadings ranging from 0.697 to 0.953 . Factor 3 had six items with factor loadings ranging from 0.740 to 0.848 . Factor 4 comprised of two items with factor loadings ranging from 0.855 to 0.805 and Factor 5 had one item with factor loading 0.964 .
Based on the variable components under each factor labelling of factor was taken up as given in Table 3.

Agricultural technology \& input services, policy, knowledge \& information support, infrastructure, weather \& technological constraints, farm management and market orientation and access to extension services were the delineated factors.

For the tribal farmers the most important factor needed to continue their farming as livelihood is the availability of agricultural inputs like seeds, fertilizers and plant protection particulars. As they had very poor facilities for transportation as well as for the purchase of agri-input services, their major concern for this would naturally be high.

Tribes being ethnic communities with comparatively low innovativeness, specific targeted policies or schemes should be implemented to keep them in track. The very clear example for this is the success of the" Millet village" program which was implemented in the area to promote and sustain the cultivation of certain millet crops.

It was well accepted and with the advantage of assured seeds, inputs and information under the scheme it revived the generations old millet cultivation in the area. Moreover, the nature and the terrain of the land has undergone changes as a result of continuous happening of natural calamities and weather changes which need special package programs.

It was these constraints that compelled many of the traditional farming families to leave agriculture as their means of livelihood. Therefore, any intervention in promoting agriculture in the region needs to be rooted in needs and regional requirements of the real farmers of Attappadi area. 
Table.1 Profile characteristics of Attappadi tribes of Kerala ( $N=300)$

\begin{tabular}{|l|l|c|l|}
\hline $\begin{array}{l}\text { Sl. } \\
\text { No. }\end{array}$ & Profile character (with unit) & $\begin{array}{c}\text { Average } \\
\text { value } \\
\text { per cent) }\end{array}$ & $\begin{array}{l}\text { Score value range \& } \\
\text { Interpretation* }\end{array}$ \\
\hline $\mathbf{1 .}$ & Education (years in school) & 39 & Illiterate \\
\hline $\mathbf{2 .}$ & Social Participation (score) & 73 & $8-24, \mathrm{~L}$ \\
\hline $\mathbf{3 .}$ & Contact with extension agency (score) & 100 & $6-12, \mathrm{~L}$ \\
\hline $\mathbf{4 .}$ & Leadership (score) & 59 & $5-15, \mathrm{H}$ \\
\hline $\mathbf{5 .}$ & Media Exposure (score) & 100 & $6-12, \mathrm{~L}$ \\
\hline $\mathbf{6 .}$ & Innovativeness & 100 & $5-15, \mathrm{~L}$ \\
\hline $\mathbf{7}$ & Monthly expenditure (Rs) & 37 & $3000-3500$ \\
\hline $\mathbf{8 .}$ & Monthly income (Rs) & 32 & $10000-15000$ \\
\hline $\mathbf{9 .}$ & Concern towards weaker section (score) & 67 & $4-8, \mathrm{~L}$ \\
\hline $\mathbf{1 0 .}$ & Availability of electric power (No) & 91 & With electricity at home \\
\hline $\mathbf{9 .}$ & Sanitation facility (No) & 91 & With toilets in their home \\
\hline & Type of house(No) & 38 & Brick/laterite walled \&thatched \\
\hline & Distance to drinking water(No) & 81 & House premises \\
\hline & Land owned (Cents) & 24 & Owning 150 cents \\
\hline
\end{tabular}

*H= High, L=Low

Table.2 Major crops cultivated in Attappadi tribal belt during 2019-20

\begin{tabular}{|l|l|l|l|c|l|}
\hline SI. No. & \multicolumn{1}{|c|}{ Crop } & \multicolumn{3}{|c|}{ Area (ha) } & \multicolumn{1}{|c|}{ Season } \\
\cline { 3 - 6 } & Agali & Pudur & Sholayur & \\
\hline $\mathbf{1}$ & Banana & 1514 & 30 & 750 & Oct-Nov to Aug-Sept \\
\hline $\mathbf{3}$ & Vegetables & 34 & 30 & 60 & Aug-Oct, Nov-Jan \\
\hline $\mathbf{4}$ & Ragi & 75 & 75 & 65 & $\begin{array}{l}\text { May to August, } \\
\text { Sept to Dec }\end{array}$ \\
\hline $\mathbf{5}$ & Bajra & 20 & 20 & 10 & $\begin{array}{l}\text { May to August, } \\
\text { Sept to Dec }\end{array}$ \\
\hline $\mathbf{6}$ & Sorghum & 20 & 20 & 15 & $\begin{array}{l}\text { May to August, } \\
\text { Sept to Dec }\end{array}$ \\
\hline $\mathbf{7}$ & Thina & 20 & 20 & 20 & $\begin{array}{l}\text { May to August, } \\
\text { Sept to Dec }\end{array}$ \\
\hline $\mathbf{8}$ & Red gram & 35 & 35 & 52 & $\begin{array}{l}\text { May to August, } \\
\text { Sept to Dec }\end{array}$ \\
\hline $\mathbf{9}$ & Cow pea & 20 & 20 & 30 & $\begin{array}{l}\text { May to August, } \\
\text { Sept to Dec }\end{array}$ \\
\hline $\mathbf{1 0}$ & Ground nut & 40 & 40 & 60 & $\begin{array}{l}\text { May to August, } \\
\text { Sept to Dec }\end{array}$ \\
\hline
\end{tabular}

(Source: Basic data compiled from local Agricultural Extension Offices, 2019) 
Table.3 Factor analysis statistics related to the factors influencing tribal farming

\begin{tabular}{|c|c|c|c|}
\hline Factors & Eigenvalue & Variance (\%) & $\begin{array}{c}\text { Cumulative variance } \\
(\mathbf{\%})\end{array}$ \\
\hline $\mathbf{1}$ & 10.016 & 43.55 & 43.55 \\
\hline $\mathbf{2}$ & 5.750 & 24.99 & 68.54 \\
\hline $\mathbf{3}$ & 2.976 & 12.94 & 81.48 \\
\hline $\mathbf{4}$ & 1.492 & 6.49 & 87.97 \\
\hline $\mathbf{5}$ & 1.044 & 4.54 & 92.51 \\
\hline
\end{tabular}

Table.4 Factors influencing tribal farming in Attappadi region of Kerala

\begin{tabular}{|c|c|c|c|}
\hline Factor & Variables & Factor label & Factor Loadings \\
\hline \multirow[t]{8}{*}{1} & Access to institutional credit & \multirow{8}{*}{$\begin{array}{l}\text { Agricultural } \\
\text { technology \& input } \\
\text { services }\end{array}$} & .696 \\
\hline & $\begin{array}{l}\text { Support from input dealers, Agri } \\
\text { business companies, Agri clinics and } \\
\text { Agri business centers }\end{array}$ & & .807 \\
\hline & $\begin{array}{l}\text { Adequacy and timely availability of } \\
\text { agricultural inputs }\end{array}$ & & .696 \\
\hline & Complexity of available technology & & .756 \\
\hline & Market demand for cultivated crops & & .874 \\
\hline & $\begin{array}{l}\text { Adequacy of availability of market } \\
\text { infrastructure }\end{array}$ & & .874 \\
\hline & $\begin{array}{l}\text { Benefits availed from government } \\
\text { schemes and policies }\end{array}$ & & .962 \\
\hline & Suitability of existing cropping pattern & & .962 \\
\hline \multirow[t]{6}{*}{2} & Farm mechanization & \multirow{6}{*}{$\begin{array}{l}\text { Policy, knowledge \& } \\
\text { information support }\end{array}$} & .953 \\
\hline & $\begin{array}{l}\text { Access to research and extension } \\
\text { services }\end{array}$ & & .953 \\
\hline & Real time market information & & .911 \\
\hline & Cost effectiveness of mechanization & & .882 \\
\hline & Government policy support & & .882 \\
\hline & Knowledge on crop management? & & .697 \\
\hline \multirow[t]{6}{*}{3} & Irrigation facilities & \multirow{6}{*}{$\begin{array}{l}\text { Infrastructure, } \\
\text { weather \& } \\
\text { technological } \\
\text { constraints }\end{array}$} & .848 \\
\hline & Availability of electricity & & .833 \\
\hline & $\begin{array}{l}\text { Access to innovative technologies for } \\
\text { the cropping system }\end{array}$ & & .815 \\
\hline & Presence of organized marketing system & & .797 \\
\hline & $\begin{array}{l}\text { Economic feasibility and technical } \\
\text { viability of practices }\end{array}$ & & .769 \\
\hline & Suitability of weather & & .740 \\
\hline \multirow[t]{2}{*}{4} & $\begin{array}{l}\text { Do you have a clear idea about where to } \\
\text { sell your produce? }\end{array}$ & \multirow{2}{*}{$\begin{array}{l}\text { Farm management } \\
\text { and market } \\
\text { orientation }\end{array}$} & .855 \\
\hline & $\begin{array}{l}\text { Do you have adequate labours to } \\
\text { manage your farm }\end{array}$ & & .805 \\
\hline 5 & $\begin{array}{l}\text { Do you have extension access to get the } \\
\text { technologies? }\end{array}$ & $\begin{array}{l}\text { Extension service } \\
\text { access }\end{array}$ & .964 \\
\hline
\end{tabular}




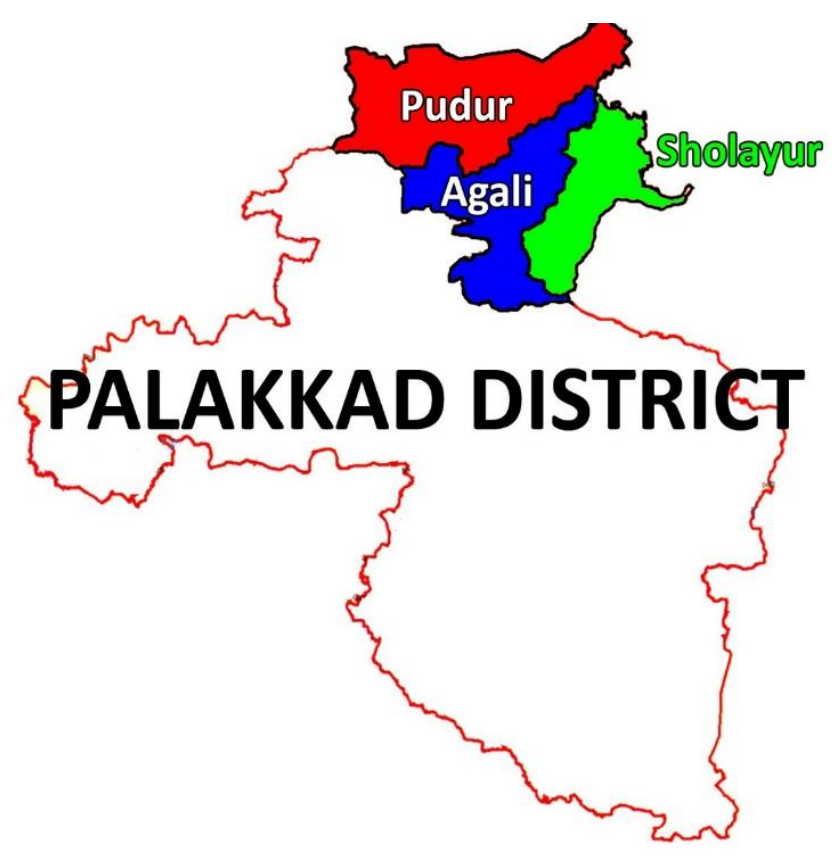

Fig.1 Map of Palakkad showing the panchayats of study

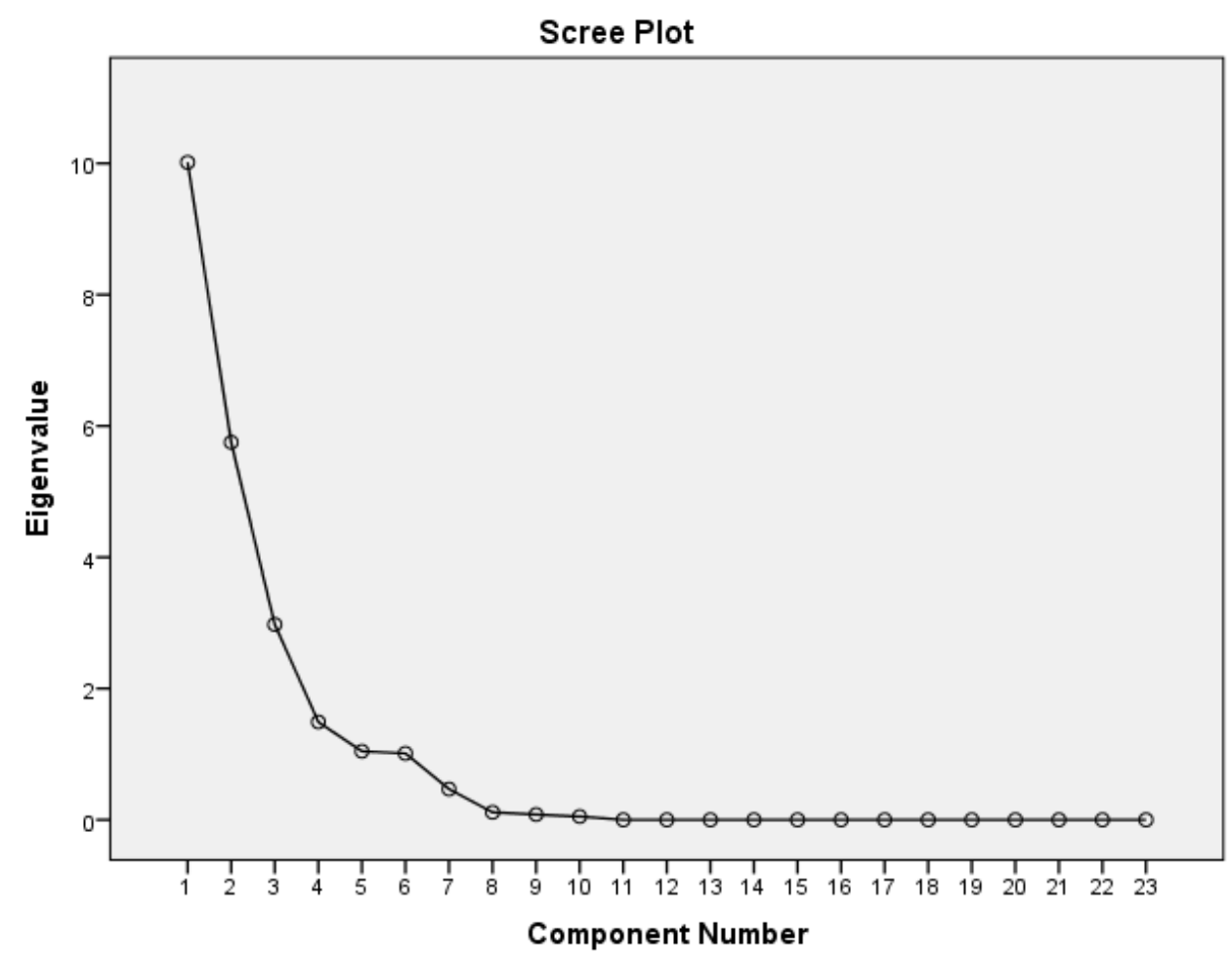

Fig.2 Scree plot depicting the major factors delineated

Traditionally tribal communities in Attappadi depended on agriculture based on indigenous knowledge gained through oral tradition and practice over generations for their livelihood. The prevalence of community ownership of land among them had the advantage of 
providing access to required land for cultivation. This enabled them to grow their traditional crops in sufficient quantities that ensured their food and nutritional security. Agricultural technology and input services, policy, knowledge and information support, infrastructure, weather \& technological constraints, farm management and market orientation and access to extension services were found to be the factors determining for the selection of farming strategy and agricultural technologies. A message from these tribal farmers would also strengthen climate change adaptability among distressed farmers and help the state and policy makers overcome the agrarian crisis. Therefore it is important for the government to have a better recognition of the inherent strength of tribal agriculture. Every effort should be to build further on these assets instead of neglecting traditional insights and farming wisdom rooted in tribal culture.

\section{References}

Jalaja, V. and Kala, P. A. (2015). Case Study of Tribal Farmers' Agricultural Information Needs and Accessibility in Attappady Tribal Block, Palakkad. J. Humanities Social Sci. 20( 8): 7-12.
(2018). Importance of Sustainable Agriculture in Tribal Community of India. Int. J. Bio-resour. Stress Manag. 9(2): 253-256.

Premakumar, K., Anandan, R. and Nagarathinam, S. (2015). A study on crop combination regions in Palakkad district, Kerala. Int. J. Geomatics Geosci. 6(2):1430-1441.

Sachana, P. C. 2015. Analysis of livelihood issues of tribal women: The case of Palakkad district. M.Sc (Ag) thesis, Kerala Agricultural University, Thrissur. 39p.

Sankar, S. and Muraleedharan, P.K. (1990). Human ecology in Attappady reserve. In: Nair, K.K.N., Bhat, K. V., Sharma, J. K. and Swarupanandan, V. (Ed.) Tropical Forest Ecosystem Conservation and Development in South and South-East Asia. Proceedings of the MAB Regional Training Workshop.1-13 May 1989, Peechi. Kerala Forest research Institute: p127-131.

Tabachnick, B. G. and Fidell, L. S. (2001) Using Multivariate Statistics. Fourth Edition. Needham Heights, MA: Allyn \& Bacon, Hardcover.

Patidar, J., Kumhar, B., Mhaske, S. and Jat, S.

\section{How to cite this article:}

Sachana, P. C. and Binoo P. Bonny. 2020. Factors Influencing Tribal Farming: Case of Attappadi Tribes in Kerala. Int.J.Curr.Microbiol.App.Sci. 9(06): 3561-3569. doi: https://doi.org/10.20546/ijcmas.2020.906.419 